Original Article

\title{
Efficacy of Prophylactic Intraoperative Povidone-lodine Solution Irrigation in Preventing Surgical Site Infection Following Spinal Surgery
}

\author{
Imran Altaf, Ammara Liaqat, Manzoor Ahmad \\ Department of Neurosurgery, Khawaja Muhammad Safdar Medical College, Sialkot, Pakistan
}

\begin{abstract}
Objective: Deep wound infection can worsen clinical outcome and increase costs following spinal surgery. The bactericidal activity of povidone-iodine covers a broad spectrum of pathogens including methicillinresistant Staphylococcus aureus. Our study aimed at evaluating the role that intraoperative dilute povidoneiodine solution irrigation could play in preventing post-operative wound infection following spinal surgery.

Material and Methods: The clinical data of 41 patients that had undergone posterior spinal surgery in the department of neurosurgery Allama lqbal hospital Sialkot was retrospectively analyzed. We divided the patients into two groups. In group 1 patients wounds were irrigated with $0.35 \%$ povidone-iodine solution prior to closure. In group 2 patients wounds were irrigated with normal saline only. The two groups were then compared for evaluation of efficacy of peroperative povidone-iodine solution irrigation in preventing postoperative wound infection.
\end{abstract}

Results: No infection occurred in the 16 patients in group 1 in whom wounds had been irrigated with povidone-iodine solution, compared to 3 deep infections developing in the 25 patients in group 2 in whom wounds had been irrigated with normal saline only. In the 3 patients that suffered from deep infections the duration of hospital stay was also significantly increased $(P<0.05)$.

Conclusion: Our study supports the notion that perioperative povidone-iodine irrigation is an effective adjunct measure for prevention of surgical site infection following spinal surgical interventions.

Keywords: Intraoperative povidone-iodine irrigation, spinal surgery, deep wound infection.

\section{Corresponding Author: Imran Altaf}

Department of Neurosurgery, Khawaja Muhammad Safdar Medical College, Sialkot, Pakistan

Date of Submission: 31-05-2020

Date of Revision: 25-01-2021

Date of Online Publishing: 26-03-2021

Date of Print: 31-03-2021

Doi: $10.36552 /$ pjns.v25i1.313

\section{INTRODUCTION}

Deep wound infection following spinal surgery is a dreaded complication with reported incidence in literature ranging from 0.5 to $13 \% .^{1}$ These wound infections continue to jeopardize patients' clinical outcome following spinal interventions despite recent advances in the fields of postoperative care and surgical technique. Such infections place the patients at increased risk for 
developing adverse neurological sequelae, and increase the chances of complications such as chronic pain or deformity. ${ }^{2}$ They may significantly increase morbidity in patients besides leading to substantially increased costs of healthcare. , $^{2,3}$ Treating these infections could prove to be a challenging proposition and they may require prolonged hospital stay, long-term antibiotic therapy and sometimes even surgical debridement. $^{5}$

Different adjunctive measures such as peroperative application of disinfectants or local antibiotics, or the employment of physical measures such as the prophylactic placements of drains are reportedly efficacious in reducing the incidence of postoperative infections. ${ }^{2}$ Local administration of powdered Vancomycin and intraoperative dilute povidone-iodine solution irrigation have also been reported to be effective in preventing postoperative spinal wound infectons. ${ }^{6,7}$ We designed the present study for assessing the role that dilute povidone-iodine solution irrigation could play in preventing postoperative wound infection after spinal surgery.

\section{MATERIAL AND METHODS}

\section{Study Design}

This was retrospective observational study. The medical records of patients that had undergone posterior spinal surgery in the department of neurosurgery Allama lqbal Hospital Sialkot from $1^{\text {st }}$ January to $31^{\text {st }}$ August 2017 were retrospectively analyzed.

\section{Inclusion Criteria}

All adult patients that had undergone posterior spinal surgery were included in the study. The patients did not show any clinical signs of infection prior to surgery, and it was the initial spinal surgery procedure for all of them.

\section{Exclusion Criteria}

Patients with a history of a previous spinal surgery or showing clinical signs of infection prior to surgery were excluded.

\section{Patient Groups and Management Protocol}

We divided the patients into 2 groups. Group 1 consisted of patients in whom wounds had an irrigation with $0.35 \%$ povidone-iodine solution that was left in place for $3 \mathrm{~min}$ at the end of the procedure before closure of wound followed by irrigation with normal saline to remove this povidone-iodine solution. No additional wound irrigation was done afterwards. In contrast, in patients in group 2 wounds had an irrigation with normal saline only at the end of the procedure. The operations were performed in standard operation theatres that did not have the facility of ultraviolet lights for disinfection, laminar flow or isolation suits. All patients were treated in the same postoperative manner with the routine analgesic pain control and postoperative antibiotics. We followed all the patients for at least 3 months postoperatively.

\section{Infection Diagnosis and Management}

The diagnosis of postoperative deep infection (below lumbosacral fascia) was established on a clinical basis with symptoms of severe back ache not getting relieved by rest, limited range of motion, muscle spasms, physical examination revealing tenderness of the back and occasional association with features of inflammation such as fever (above $38^{\circ} \mathrm{C}$ ). We confirmed all deep infections by laboratory parameters including the erythrocyte sedimentation rate (ESR). These patients were initially managed conservatively with antibiotics. Surgical intervention was done in patients that did not improve with conservative treatment with open debridement of the wound. 


\section{Data Analysis}

Statistical analysis was performed with chi-square test for povidone-lodine solution irrigation, and an independent t-test for hospitalization to assess their relationship with post-operative infection after spinal surgery. A p-value of $<0.05$ was considered to be statistically significant for all analysis.

\section{RESULTS}

\section{Gender Distribution}

The medical records of 41 patients that had undergone posterior spinal surgery were analyzed. There were 24 males and 17 females.

\section{Age Distribution}

Group 1 in which povidone-iodine solution irrigation had been done included sixteen patients. The mean age of patients in this group was 45 years. Group 2 included twenty five patients. The mean age of patients in this group was 39.23 years.

\section{Clinical Presentation}

The different spinal pathologies operated are listed in table 1.

\begin{tabular}{|lc|}
\hline Table 1: Incidence of spinal pathologies operated \\
Pathology & No of Patients \\
Prolapsed intervertebral disc & 33 \\
Spinal stenosis & 5 \\
Spinal tumors & 3 \\
\hline
\end{tabular}

In Group 1, that included sixteen patients the pathologies operated included the excision of two spinal SOLs, one decompressive laminectomy for spinal stenosis, and laminectomy and excision of prolapsed intervertebral discs in thirteen cases. No infection was reported in this group.
In Group 2, that included twenty five patients the operated pathologies included the excision of one spinal SOL, decompressive laminectomy for four cases of spinal stenosis, and laminectomy and excision of twenty cases of prolapsed intervertebral discs. Three deep infections occurred in this group. The average time of presentation of these three patients was 56.7 days postoperatively. These 3 patients remained hospitalized for an average of 23 days. These patients were initially managed conservatively with third generation Cephalosporin, Linezolid and ATT. One patient was managed successfully with this conservative treatment, while in the other two patients the wound had to be reopened and debridement done after which the patients recovered.

Although all the three post-operative infections occurred in group 2 where povidoneiodine had not been used, with no infection occurring in the povidone-iodine group, the relationship of povidone-iodine irrigation with prevention of postoperative infection was found to be not statistically significant $(p=0.15)$.

Table 2: Relationship of povidone-iodine irrigation with prevention of postoperative infection.

\begin{tabular}{lccc} 
Groups & $\begin{array}{c}\text { Non-SSi } \\
(\mathbf{n}=\mathbf{3 8})\end{array}$ & $\begin{array}{c}\text { SSi } \\
(\mathbf{n}=\mathbf{3})\end{array}$ & p-value \\
$\begin{array}{l}\text { Povidone-iodine } \\
\text { group }\end{array}$ & 16 & 0 & \\
$\begin{array}{l}\text { Non-povidone- } \\
\text { iodine group }\end{array}$ & 22 & 3 & 0.15 \\
\hline
\end{tabular}

SSi = Surgical Site Infection

The duration of hospitalization was found to be significantly increased $(p<0.05)$ in patients suffering from post-operative infection. The relationship between duration of hospitalization and postoperative infection is given in table 3 . 
Table 3: Relationship between duration of hospitalization and postoperative infection.

\begin{tabular}{|c|c|c|c|}
\hline & $\begin{array}{l}\text { Non-SSi } \\
(n=38)\end{array}$ & $\begin{array}{c}\text { SSi } \\
(n=3)\end{array}$ & p-value \\
\hline $\begin{array}{l}\text { Hospitalization } \\
\text { (mean) }\end{array}$ & 3.6 days & 23 days & $<0.0000001$ \\
\hline
\end{tabular}

\section{DISCUSSION}

Post-operative spinal wound infection could be a devastating complication which can compromise the clinical outcome of spinal procedures including even simple spinal procedures such as multilevel decompression or discectomy. Preventing these infections rather than treating them postoperatively would clearly be the preferred option as they are still a rather frequent occurrence despite the adoption of aseptic techniques and use of prophylactic antibiotics. ${ }^{8}$ These surgical site infections increase the morbidity in patients undergoing spinal interventions, and place an immense burden on the health care system. ${ }^{3,4,9}$ Veeravagu et $\mathrm{al}^{10}$ found that in patients suffering from wound infection following spinal surgery the hospital stay gets prolonged, morbidity and mortality increases and there are higher rates of patients requiring a revision surgery, as compared to patients who remain infection free. These infections also increase the cost of healthcare; Calderone et $\mathrm{al}^{11}$ estimated that the cost of health care management could rise by four fold if a post-operative infection occurs after spinal surgery.

Although many peroperative measures have been utilized for reducing infections following spinal surgical interventions, but only a few studies have as yet been published on the topic, and those too carrying only low level evidence. The most commonly employed adjunct measures for prevention of infections following spinal surgical procedures are to preoperatively irrigate the wound with Povidone-lodine (PVP-I) or hydrogen peroxide and saline solution, or to carry out closed suction drainage of the wound. In clinical practice Povidine-lodine is usually utilized as a surgical scrub, for disinfecting open wounds and to treat both superficial and deep infections. It has been considered compared to chlorhexidine and other antibiotics, the one having the highest bactericidal activity and the lowest cytotoxic effects. ${ }^{12}$

The present study was designed to assess the beneficial effects of peroperative PVP irrigation in preventing postoperative spinal infections. Although the relationship between Povidonelodine irrigation and prevention of postoperative infection was found to be not statistically significant ( $p=0.15$ ), yet it was clear that no infection had occurred in our study in patients in whom peroperative Povidone-lodine irrigation had been done. Our findings are thus consistent with the findings of Fang-Yeng Chang et $\mathrm{al}^{1}{ }^{1}$ Cheng MT et $\mathrm{al}^{7}{ }^{7}$ Vincenzo De Luna et $\mathrm{al}^{12}$ and Simone Ulivier et $\mathrm{al}^{13}$ who also found that no infection occurred in patients in whom peroperative Povidone-lodine had been used. Our study thus supports the idea of povidoneiodine irrigation as being an effective therapeutic adjunct measure for prevention of surgical site infection following spinal surgery.

Our study also found that post-operative infection significantly increases $(p<0.05)$ hospital stay, and is thus consistent with the study of Veeravagu et $\mathrm{al}^{10}$ that showed that in patients suffering from a wound infection following spinal surgery the hospital stay gets prolonged.

\section{Limitations of the Study}

Our study is a retrospective, non-randomized study that had a small sample size. Furthermore, we only included patients that developed deep wound infections. We believe that further research with a quantitative controlled prospective study having a large sample size is warranted to clearly define the role that Povidone-lodine solution irrigation has in the 
prevention of postoperative infections after spinal surgery.

\section{CONCLUSION}

Our study supports the notion that perioperative povidone-iodine irrigation is an effective therapeutic measure for prevention of surgical site infection following spinal surgical interventions.

\section{REFERENCES}

1. Fang-Yeng Chang, Ming-Chau Chang, Shih-Tien Wang, Wing-Kwang Yu, Chien-Lin Liu, and TainHsiung Chen. Can povidone-iodine solution be used safely in a spinal surgery? Eur Spine J. 2006; 15 (6): 1005-1014.

2. Abhijit Yuvaraj Pawar, Samar Kumar Biswas. Postoperative Spine Infections. Asian Spine J. 2016; 10 (1): 176-183.

3. Jad Chahoud, Zeina Kanafani and Souha S. Kanj. Surgical Site Infections Following Spine Surgery: Eliminating the Controversies in the Diagnosis. Front Med (Lausanne). 2014; 1: 7.

4. Vishal Hegde, Dennis S Meredith, Christopher K Kepler, and Russel C Huang. Management of postoperative spinal infections. World J Orthop. 2012; 3 (11): 182189.

5. Wen Wei Gerard Ee, Wen Liang Joel Lau, William Yeo, Yap Von Bing, Wai Mun Yue. Does Minimally Invasive Surgery Have a Lower Risk of Surgical Site Infections Compared With Open Spinal Surgery? Clin Orthop Relat Res. 2014; 472 (6): 1718-1724.
6. Robert W. Molinari, Oner A. Khera, and William J. Molinari III. Prophylactic intraoperative powdered vancomycin and postoperative deep spinal wound infection: 1,512 consecutive surgical cases over a 6-year period. Eur Spine J. 2012; 21 (Suppl. 4): 476482.

7. Cheng MT, Chang MC, Wang ST, Yu WK, Liu CL, Chen TH. Efficacy of dilute betadine solution irrigation in the prevention of postoperative infection of spinal surgery. Spine (Phila Pa 1976), 2005; 30 (15): 1689-93.

8. Salman Sharif, Farhan Gulzar. Postoperative Infections of the Spine. WSc J. 2015; 1: 19-26.

9. J. J. P. Schimmel, P. P. Horsting, M. de Kleuver, G. Wonders, J. van Limbeek. Risk factors for deep surgical site infections after spinal fusion. Eur Spine J. 2010; 19 (10): 1711-1719.

10. Veeravagu A, Patil CG, Lad SP, Boakye M. Risk factors for postoperative spinal wound infections after spinal decompression and fusion surgeries. Spine (Phila Pa 1976), 2009; 34 (17): 1869-72.

11. Calderone RR, Garland DE, Capen DA, Oster H. Cost of medical care for postoperative spinal infections. Orthop Clin North Am. 1996; 27 (1): 171-82.

12. De Luna V, Mancini F, De Maio F, Bernardi G, Ippolito E, Caterini R. Intraoperative Disinfection by Pulse Irrigation with Povidone-lodine Solution in Spine Surgery. Adv Orthop. 2017; 2017: 7218918.

13. Ulivieri S, Toninelli S, Petrini C, Giorgio A, Oliveri G. Prevention of post-operative infections in spine surgery by wound irrigation with a solution of povidone-iodine and hydrogen peroxide. Arch Orthop Trauma Surg. 2011; 131 (9): 1203-6

\section{Additional Information}

Disclosures: Authors report no conflict of interest.

Ethical Review Board Approval: As our study is a retrospective study so ethics committee approval was not required.

\section{Conflicts of Interest:}

In compliance with the ICMJE uniform disclosure form, all authors declare the following:

Financial Relationships: All authors have declared that they have no financial relationships at present or within the previous three years with any organizations that might have an interest in the submitted work.

Other Relationships: All authors have declared that there are no other relationships or activities that could appear to have influenced the submitted work. 


\section{AUTHORS CONTRIBUTIONS AFTER REVISION}

\begin{tabular}{|l|l|l|}
\hline Sr.\# & Author's Full Name & Intellectual Contribution to Paper in Terms of: \\
\hline 1. & Imran Altaf & $\begin{array}{l}\text { Study design, methodology, paper writing, literature review, } \\
\text { interpretation of results, referencing and data calculation. }\end{array}$ \\
\hline 3. & Imran Altaf \& Ammara Liaqat & Data collection \\
\hline 6. & Manzoor Ahmad & quality insurer \\
\hline
\end{tabular}

